\title{
Introduction by the Editor-in-Chief
}

The annotated case law and commentaries in this journal, the second issue of the International Labor Rights Case Law (ILaRC), underline the relevance and legal complexity of the right to strike around the world, in relation to both national and international labor regulation.

In January, in Saskatchewan Federation of Labourv. Saskatchewan, the Canadian Supreme Court ruled that the right to strike is a guaranteed right directly linked to the freedom of association, and struck down provincial legislation that limited the right to strike by workers considered by the government to be providers of essential services. Justice Abella determined that "the right of employees to strike is vital to protecting the meaningful process of collective bargaining".

Meanwhile, in South Africa, in Chamber of Mines of South Africa v. Association of Mineworkers of South Africa et al, the Labor Court determined that prohibitions on the right to strike are permitted only when they relate to particular issues, serve a legitimate purpose, and where there is no less restrictive means to achieve the legitimate purpose. International standards played a strong role in the Court's ruling. This was also the case in the ILO's Committee on Freedom of Association's March 2015 assessment of a complaint against the Government of Turkey. The Committee found that a provision allowing the government to suspend a strike by way of a decree and to impose compulsory arbitration failed to adhere to internationally recognized standards and jurisprudence developed by the Committee and the European Court for Human Rights since the 1970s.

This ILaRC issue additionally serves to emphasize the wide variety of decisionmaking entities that address fundamental labor rights: national criminal courts, ILO Committees, Supreme Courts, United Nations treaty bodies, and the courts of the European Union, amongst many other judicial and quasi-judicial bodies. Whilst all these entities together provide relevant avenues for potential victims of labor rights abuses to be heard, their multiplicity also increases the complexity of the system, and the inconsistency in decisions is sometimes a source of disconcertion for legal analysts. Some of the commentaries in this issue address this dilemma.

The Editorial Team welcomes suggestions from our subscribers of cases for inclusion in later issues via ILaRC@TheHagueInstitute.org.

\section{Paulvan der Heijden}

Leiden, The Netherlands

June 2015

(C) PAUL VAN DER HEIJDEN, 2015 | DOI 10.1163/24056901-00102001 